\title{
BILINGUAL AND REGULAR CLASS STUDENTS' ATTITUDES TOWARDS ENGLISH
}

\author{
Nihta V.F. Liando \\ Faculty of Languages and Arts, Manado State University \\ e-mail: nihta_liando@yahoo.com
}

\begin{abstract}
This article presents the results of the study investigating the relationship between the students' attitudes towards English and their English achievements in bilingual and regular classes and investigating the differences. The study was conducted in a junior high school in Manado. There are 30 Year VIII students in each bilingual class and each regular class. The results are as follows. First, there is a significant correlation between the students' attitudes towards English and their achievements. Second, there is a significant difference in their English achievements between bilingual class students and regular students. Third, female students have higher English achievements than male students. Bilingual class students have more positive attitudes and higher English learning achievements than regular class students.
\end{abstract}

Keywords: attitudes, English as a foreign language, bilingual, learning achievements

\section{SIKAP TERHADAP BAHASA INGGRIS SISWA KELAS BILINGUAL DAN REGULER}

\begin{abstract}
Abstrak
Artikel ini memaparkan hasil penelitian yang mengkaji hubungan sikap siswa terhadap bahasa Inggris dan hasil belajar mereka dalam mata pelajaran bahasa Inggris di kelas bilingual dan kelas reguler dan mengkaji perbedaan yang muncul. Penelitian ini dilakukan pada sebuah sekolah menengah pertama di Manado. Terdapat 30 siswa kelas 8 untuk setiap kelas bilingual dan reguler. Hasil penelitian sebagai berikut. Pertama, ada hubungan yang signifikan antara sikap siswa terhadap bahasa Inggris dan hasil belajar mereka. Kedua, ada perbedaan yang signifikan antara hasil belajar siswa kelas bilingual dan kelas reguler untuk mata pelajaran bahasa Inggris. Ketiga, siswa perempuan memiliki hasil belajar bahasa Inggris yang lebih tinggi daripada dengan siswa laki-laki. Siswa kelas bilingual memiliki sikap positif yang lebih baik dan hasil belajar yang lebih tinggi dalam pembelajaran bahasa Inggris daripada siswa kelas reguler.
\end{abstract}

Kata kunci: sikap, bahasa Inggris sebagai bahasa asing, bilingual, hasil belajar

\section{INTRODUCTION}

In these changing foreign language learning circumstances, it has long been apparent that there are some students who are better at learning foreign languages than others (Bilyeu, 1982). Although students have been considered the primary focus of the teaching and learning processes, research focusing on students as the centre of teaching and learning did not begin until the 1970s (Oller \& Richards,1973; Rubin, 1975). Since then the focus on students' attitudes as central to the teaching and learning process has attracted the interest of researchers and has become an important consideration in research undertaken to enhance learning outcomes. In relation to attitudes and 
learning, student motivation was found to be one variable associated with being successful in language learning.

In the early days of research on motivation, using 34 items in the University of South Carolina (USC) Inventory of Study Methods and Attitudes, a short verbal aptitude test and an achievement measure, Michael, Jones, and Trembly (1959) found that the nature of college students' motivation was complex. Gardner (1958) was considered the pioneer of research in motivation and second language learning and studied high school students learning French as a second language (Gardner, 1990, 2001). These studies found motivation to be an important factor in second language learning, together with factors such as cultural beliefs and linguistic competence. As a result of a series of consecutive studies, an Attitude/Motivation Test Battery (AMTB) was developed by Gardner (1985a) to measure students' motivation when learning a second language. The AMTB used variables such as attitudes toward French Canadians, attitudes toward learning French, interest in foreign languages, ratings of instrumental and integrative orientations, parental encouragement, and general classroom anxiety. Although Gardner's research was originally conducted in the Canadian context, the methodology and use of the AMTB eventually spread to other countries. As Gardner and MacIntyre (1993:3) stated "many studies have used versions of the AMTB in contexts other than those involving English Canadian students learning French as a second language".

There have been a number of studies exploring motivation and attitude of high school students and second language learning (Abu-Rabia, 1997). Key findings of these studies suggest factors such as language aptitude and attitude toward the target language community have proved to be important in being successful in learning the target language. Learners, when they possess positive attitudes toward the target language and willingness to integrate themselves within the culture of that group and become a part of that society, are attributed as having integrative motivation.

A further series of research studies also extended Gardner's initial research. For example, Gardner, et al. (1985) investigated factors that promoted second language acquisition in two French programs - one in the second language program and the other in a secondary school French program in London, Ontario. The findings suggested a number of other variables related to foreign language learning motivation, including the learners' attitudes towards French Canadians, French course, their teacher, their interest in foreign languages, their desire to learn the target language, their need for achievement and the encouragement received from parents. In another study which replicated this work, Clement, et al. (1994) used the AMTB to assess the motivational characteristics of 304 Francophone (French-speaking) students in Grades 10 and 11 as they learned English as a second language. The findings indicated positive significant correlations between an individual's motivation to learn a second language and favorable attitudes toward the second language community (integrative motive).

Studies on motivation have expanded to foreign language learning. In these research studies, motivation in foreign language learning has been investigated in relation to a range of factors such as integrative and instrumental motivations, attitudes, and continuance of language study. Key findings in these studies support those reported in the previous section but in a context of a foreign language. Several of these studies have reported the importance of both integrative and instrumental orientation of students 
learning a foreign language.

In the Asian context, integrative and instrumental motivations have both been shown to be important in learning a foreign language such as English. For example, in exploring motivations and attitudes of 80 limited English speaking Korean high school students toward American English or British English in the formal English as a foreign language (EFL) classroom Kang (1999) found that students' language use was restricted to instrumental purposes and their orientation was both instrumental and integrative.

Similar findings were shown in a study conducted by Tamba (1993) which explored the motivation and attitudes of 1,210 French-speaking Cameroonian learners of English in 11 Yaounde secondary schools. The results showed that motivation was a significant factor for these students in learning English. This study also revealed that instrumental motives were found to be more important than integrative ones. One of the reasons was that these students considered English to be vital for trade and technology.

Clement et.al. (1994) examined the linguistic attitudes and motivations of 301 Hungarian high school students toward English as a foreign language. Factor analysis and correlational analysis of the results of a survey questionnaire revealed that instrumental orientation, together with other reasons such as social cultural, and media-use were most strongly endorsed by the students as contributing factors for being motivated to learn English. In response to the previous study, Dörnyei (1998) focused a further study on the characteristics of integrative and instrumental motivations in foreign language learning by administering questionnaires to 134 young adult learners of English in Hungary. The results showed that the variables of instrumental motivation and need for achievement played a significant role in mastering intermediate target language proficiency.

More recently, Cabral (2005) explored the attitudes and motivation of four English-speaking students in two Portuguese public schools towards their Portuguese and English language classes. Through interviews and field notes, the study results suggested that the needs of these students were not met in their Portuguese language classes nor their English language classes because of several factors such as traditional teaching methods and classroom environments which rendered students less motivated. Li (2005) conducted a research study on learners' belief and the role of learning strategy in China. Magogwe and Oliver (2007) investigated the relation among language learning, proficiency, age and belief of learners in Botswana. Similar research studies were also conducted by Loewen, Li, Fei, Thompson, Ahn, \& Chen (2009) about second language learners' belief about grammar instruction and error correction, wherea Li and Liang (2012) looked at the relationship between belief and proficiency in Chinese context. In relation to attitudes, Mills, Pajares and Herron (2006) did a re-evaluation of the role of anxiety, self-efficacy and their relation to reading and listening skills. Another study about anxiety in a foreign language class has shown the importance of this attribute in language learning (Matsuda and Gobel 2004).

The studies in this section have presented findings which suggest that students' motivation and their attitudes towards the target language play a significant role in second or foreign language learning. Key findings reveal that attitudes towards the target language and students' motivation contribute to the success of language learning. Therefore, there is a need to examine the influence of attitudes towards English in the Indonesian schools, especially in comparing between students in a bilingual 
class and those of regular class.

Most studies have used or adapted the AMTB developed by Gardner (1985a) or other forms of self-report questionnaires to collect data. Variables such as attitudes toward the language, integrative and instrumental orientation have emerged as most frequently examined variables in these studies.

\section{METHOD}

This research employed quantitative method with a questionnaire as the instrument to determine the variable of students' attitude toward English language and the English achievement stated in the odd semester report as the variable of students' achievement in English language subject. The questionnaire was distributed to 30 students in a billingual class and 30 in a regular class as sample of this research.

The questionnaire format was chosen because it is an efficient method forgathering data from a large number of participants (Judd, Smith, \& Kidder, 1991). The questionnaire was administered to students. The questionnaire consisted of two parts

Part I gathered participant background information. In this part, several demographic questions were included to obtain background information from the participants. This included information regarding parents' socio-economic status (SES), educational backgrounds and accommodation types.

Part II comprised scales on attitudes toward English. This part II was based on Gardner's (1985a) attitude toward learning English with 10 items. Responses to the questionnaire were rated as Strongly Disagree $(\mathrm{SD})=1$, Disagree $(\mathrm{D})=2$, Neutral $(N)=3$, Agree $(A)=4$, and Strongly Agree $(\mathrm{SA})=5$, with a minimum score of 1 and a maximum of 5 .

For students' academic achievement, the grades were obtained from the Deputy Head of School in Academic Affairs and there was only one score for one subject, English. The indicator of the students' achievement was the final grades they obtained in their English subject in the first semester. These scores were calculated based on the result of mid semester and final semester exams, structured tasks, independent tasks and attendance. The results of the first semester which appeared in students' reports were used as indicators of academic achievement.

\section{FINDINGS AND DISCUSSION}

Item-scale analysis was first performed to check the internal consistency reliability of the scale. This scale had 10 items. The ten items in the Attitude toward Learning English scale showed that they are correlated to each other with an overall alpha reliability coefficient of 0.811 . Each item is interrelated with an average interitem correlation of 0.307 . The item total correlation for each item ranges from 0.284 to 0.644 . The result of item-scale analysis for the Attitude toward Learning English scale suggested that this scale was reliable for use in this study.

These are items in the scale:

Learning English is really great.

I plan to learn as much English as possible.

I really enjoy learning English.

I think it is important to learn English.

Learning English is a waste of time.

I hate English.

I prefer to spend my time on courses other than English.

I find the study of English very boring.

In my opinion, English is an important subject in the school curriculum.

I think we should spend more time in school learning English

Descriptive statistics were computed to see how the data were distributed for the two groups. The t-tests were performed to determine whether students 
in bilingual class and regular class differed on their attitudes towards learning English as a foreign language. Based on the $t$-test result the means for the scale Attitudes toward Learning English for the bilingual class were higher than those of the regular (monolingual class): 4.42 and 4.14 respectively. Both groups had means of 4 or greater, indicating high levels of agreement with the scale.

The result of $\mathrm{t}$-test has proven that students in bilingual class have better attitudes toward learning English as the consequence of being in a special class with greater exposures of English, compared to their counterparts in the regular class. This result also confirmed the findings of previous research studies of the importance of positive attitudes in learning English.

The results of student academic achievement suggested that there were significant differences between the bilingual and regular groups. The bilingual class achieved higher score $(\mathrm{M}=8.67)$ than those of regular class $(\mathrm{M}=6.97)$. The results strengthened the arguments that students in bilingual class have better English achievement compared to those of regular class. This could be the result of constant exposures of English in other subjects which led to the increasing performance in the English subject. Another interesting finding was that female students in both groups had higher scores $(\mathrm{M}=7.55)$ than male students $(M=7.09)$, thus suggesting that female students are better in learning English than the male ones.

The results of Pearson Product Moment Correlation show there was a significant correlation between attitudes toward learning English and academic achievement with $r=0.261$ at $p>0.01$ level. Furthermore there was a significant correlation between students' attitudes toward learning English and gender $(r=$ $0.150, p>0.05$ level).

This suggests that if students have positive attitudes toward learning English they would work harder to improve their academic achievement. From the findings in this study, it is also clear that many of the links found in previous research studies on motivation and second language learning that suggests that students' motivation plays an important role in success (AbuRabia 1997; Csizer \& Dornyei 2005a; Dornyei 2003; Gardner et al 2004; Masgoret \& Gardner 2003a) also exist in this study, which finds a significant correlation between attitudes toward learning English as one of the motivational factors and academic achievement. However, much of the previous research had focused on either English or French as the second language in Canadian, Hungarian, or in other European contexts. Evidence from an Indonesian context extends the scope of the earlier studies which were undertaken in Western contexts.

In terms of EFL learning in Asian contexts, findings from this suggest that it is important for teachers and school faculties to encourage students to have more positive attitudes toward English in order to achieve more satisfactory results.

\section{CONCLUSION AND SUGGESTIONS}

From the findings in this study, it is clear that many of the links found in previous research studies on attitudes toward learning English and second or foreign language learning that suggest that this aspect plays an important role in success also exist in this study, which finds a significant correlation between attitudes toward learning English and academic achievement. Evidence from the context of this study extends the scope of earlier studies which were undertaken in Western contexts. Moreover, comparing two different groups of study in terms of their attitudes toward learning English within the context of Indonesian schools enrich our understanding of the importance of establishing positive attitudes toward the subject being learned. 
Special notes:

This research was made possible under the research fund by the Research Centre of Manado State University. I am also grateful for the assistance of Prof. Karen Moni and Prof. Richard Baldauf of the University of Queensland in the writing of this paper.

\section{REFERENCES}

Abu-Rabia, S. 1997. Gender differences in Arab students' attitudes toward Canadian society and second language learning. The Journal of Social Psychology, 137(1), 125-128.

Bilyeu, E. E. 1982. Practice makes closer to perfect: Alternative techniques for teaching foreign language to learning disabled students in the university

Cabral, M. 2005. Foreign students' attitudes in Portuguese language classrooms: An exploratory study. Intercultural Education, 16(3), 279-291.

Clement, R., et. al. 1994. Motivation, selfconfidence, and group cohesion in the foreign language classroom. Language Learning, 44(3), 417-448.

Csizer, K., \& Dörnyei, Z. 2005a. The internal structure of language learning motivation and its relationship with language choice and learning effort. The Modern Language Journal, 89(1), 19-36.

Csizer, K., \& Dörnyei, Z. 2005b. Language learners' motivational profiles and their motivated learning behavior. Language Learning, 55(4), 613-659.

Dörnyei, Z. 1998. Motivation in second and foreign language learning. Language Teaching, 31, 117-135.

Dornyei, Zoltan 2006 Individual differences in second language acquisition. AILA Review 19(9), 42-68.

Gardner, R. C. 1958. Social factors in second language acquisition. Unpublished Master's thesis, McGill University.

Gardner, R. C. 1985a. The attitude/ motivation test battery: Technical report: University of Western Ontario.

Gardner, R. C. 1990. Attitudes, motivation, and personality as predictors of success in foreign language learning. In T. S. Parry \& C. W. Stansfield (Eds.), Language aptitude reconsidered (pp. 179-221). Engelwood Cliffs, NJ: Prentice Hall Regents.

Gardner, R. C. 2001, February 17 and 24. Integrative motivation: Past, present and future. Distinguished Lecturer Series, 27.

Gardner, R. C., \& Clement, R. 1990. Social psychological perspectives on second language acquisition. In H. Giles \& P. Robinson (Eds.), Handbook of language and social psychology (pp. 495-517). Chicester, NY: Wiley.

Gardner, R. C., Lalonde, R. N., \& Moorcroft, R. 1985. The role of attitudes and motivation in second language learning: Correlational and experimental considerations. Language Learning, 35(2), 207-227.

Gardner, R. C., \& MacIntyre, P. D. 1993. A student's contributions to second language learning. Part II: Affective variables. Language Teaching, 26, $1-11$.

Gardner, R. C., \& Lysynchuk, L. M. 1990. The role of aptitude, attitudes, motivation, and language use on second-language acquisition and retention. Canadian Journal of Behavioral Science, 22(3), 254-270.

Judd, C. M., Smith, E. R., \& Kidder, L. H. 1991. Research methods in social relations. Fort Worth: Holt, Rinehart and Winston.

Kang, D. H. 1999. Motivational constructs and changes in EFL classroom (Pilot Study). Retrieved 8 March 2007 from http://www.eric.ed.gov/ ERICDocs/ data/ericdocs2/content storage_01/0000000b/80/11/96/66.pdf

Li, Shoafeng and Liang, Wenxin. 2012. The dynamic nature of learner beliefs: The relationship between beliefs abput 
EFL learning and proficiency in a Chinese context. The Asian EFL Journal 14(1), 177-211.

Li, X. 2005 An analysis of Chinese EFL learners' beliefs about the role of rote learning in vocabulary strategies. The Asian EFL Journal 7(4), 109-120.

Loewen, S., Li,S., Fei, F., Thompson, A., Ahn,S., Chen, X. 2009 L2 learners belief about grammar instruction and error correction. The Modern Language Journal 93(1), 91-104.

Magogwe, J.M., Oliver R 2007 The relationship between language learning strategies, proficiency, age and self-efficacy beliefs: A study of language learners in Bostwana. System 35(3), 338-352.

Matsuda, S. and Gobel, P. 2004. Anxiety and predictors of performance in the foreign language classroom. System 32(1), 21-36.
Michael, W. B., Jones, R. A., \& Trembly, W. A. 1959. The factored dimensions of a measure of motivation for college students. Education and Psychological Measurement, 19(4), 667-671.

Oller, J. W., \& Richards, J. C. 1973. Focus on the learner: Pragmatic perspectives for the language teacher. Rowley, MA: Newbury House.

Rubin, J. 1975. What the "good language learner" can teach us? TESOL Quarterly, 9 (1), 41-51.

Tamba, T. P. 1993. Motivation in language learning - The case of Francophone Cameroonian learners of English. The English Teacher, 22. Retrieved August 26, 2004 from http://www.melta.org. my/ET/1993/main10.html 